УДК 656.071 .1

DOI:

Юрій Якімець, заступник директора Львівського автомобільно-дорожнього коледжу НУ “Львівська політехніка”

\title{
ДОСЛІДНО-ЕКСПЕРИМЕНТАЛЬНА ПЕРЕВІРКА ЕФЕКТИВНОСТІ ФОРМУВАННЯ ПРОЕКТУВАЛЬНИХ УМІНЬ У МАЙБУТНІХ ТЕХНІКІВ- МЕХАНІКІВ АВТОТРАНСПОРТНОЇ ГАЛУЗІ В ПРОЦЕСІ ВИВЧЕННЯ ПРОФЕСІЙНО-ОРІЄНТОВАНИХ ДИСЦИПЛІН
}

У статті подано результати дослідно-експериментальної перевірки ефективності формування проектувальних умінь у майбутніх техніків-механіків автотранспортної галузі в прочесі вивчення професійноорієнтованих дисииплін. За допомогою методів математичної статистики доведена достовірність кількісних даних та правильність висунутої гіпотези. Зроблено висновок про ефективність впровадження запропонованих моделі, педагогічних умов і методики та доиільність їх впровадження у процес професійноі підготовки майбутніх техніків-механіків автотранспортної галузі.

Ключові слова: проектувальні вміння; майбутні техніки-механіки; автотранспортна галузь; професійно орієнтовані дисципліни; експериментальна перевірка.

Табл. 1. Рис. 3. Літ. 6.

Yuriy Yakimets, Deputy Director Lviv Motor-Road College of National University "Lviv Polytechnic"

\section{RESEARCH AND EXPERIMENTAL VERIFICATIONOF EFFICIENCY OFFORMATION OF DESIGNING SKILLS FOR FUTURE TECHNICIANS-MECHANICS OF ROAD TRANSPORT INDUSTRY WHILE STUDYING PROFESSIONALLY ORIENTED SUBJECTS}

Nowadays the goal of vocational education is to prepare the future competitive workers, to develop their ability to respond promptly to the demands of dynamic changes in the society, as well as the ability to seek the ways to rational problem-solving independently, the ability to work with the information and information technologies. The effectiveness of these processes depends on the optimal use of methods, tools and technologies, taking into account modern approaches to professional training.

The article presents the results of the research and experimental verification of the effectiveness of the formation of designing skills of future technicians-mechanics of the road transport industry while studying professionally oriented subjects. The molding pedagogical experiment revealed a significant improvement in the quality of training technicians-mechanics of the road transport industry as a result of the implementation of the developed and tested models, the pedagogical conditions and methods. A statistical verification using Pearson's chi-squared test confirmed the hypothesis of the study and showed the feasibility of introducing the author's innovations.

The conclusion about the effectiveness of the suggested model, pedagogical conditions (namely - the development of the future mechanics' motivational-value attitude towards further creative project activities; the continuity and interconnection of theoretical knowledge and practical designing skills; mastering the complex of designing skills with the help of specialized ICT tools; the integration of professional and designing skills while performing the diploma project), the author's methods and the feasibility of their implementation into the process of future technicians-mechanics of the road transport industry training is made.

Keywords: designing skills; future mechanics; motor transport industry; technical schools; professionally oriented subjects; experimental verification.

П остановка проблеми. На сучасному етапі метою професійної освіти $\epsilon$ формування у майбутніх фахівців конкурентоспроможності, умінь оперативно реагувати на запити динамічних змін суспільства, а також здатності самостійно шукати способи раціонального вирішення проблем, вміння працювати 3 інформацією та інформаційними технологіями. Ефективність цих процесів залежить від оптимального використання методів, засобів і технологій з урахуванням сучасних підходів до професійної підготовки фахівців.

Аналіз основних досліджень і публікацій. Проблема якісної підготовки майбутніх фахівців різних профілів до проектувальної діяльності розглядалася в таких напрямах, як: теоретичні основи професійної педагогіки (А. Ашеров, С. Батишев, В. Беспалько, С. Гончаренко, Е. Зеєр, В. Серіков, В. Сластьонін та ін.); вдосконалення системи професійної освіти на основі 
компетентнісного підходу (А. Андрєєв, - 2017 рр. у шести закладах освіти України, В. Аніщенко, І. Зимня, Л. Лук’янова, О. Овчарук, передусім, у Львівському автомобільноА. Хуторський та ін.); педагогічні аспекти проектувальної діяльності і формування проектувальних вмінь в різних закладах освіти (В. Бербец, Н. Брєднєва, О. Коберник, В. Кошелева, Н. Кузьміна, В. Сидоренко та ін.). Проте, на жаль, педагогічна наука приділяє недостатньо уваги питанням формування проектувальних умінь у змісті професійної підготовки фахівців технічного профілю, зокрема автотранспортної галузі.

3 огляду на це, наша дослідноекспериментальна робота спрямовувалась на дослідження впливу на якість підготовки техніківмеханіків автотранспортної галузі інноваційних заходів, запропонованих нами протягом тривалого дослідження.

Мета статті полягає у висвітленні отриманих експериментальних даних щодо ефективності формування проектувальних умінь у майбутніх техніків-механіків автотранспортної галузі в процесі вивчення професійно-орієнтованих дисциплін і перевірки гіпотези про те, що підготовка техніків-механіків до проектної діяльності з урахуванням сучасних підходів до модернізації змісту, форм організації і методів навчання в коледжі підвищує якість професійної компетентності та розвиває творчий потенціал студентів.

Виклад основного матеріалу. Експериментальна робота грунтувалась на методиці організації педагогічних досліджень П. Воловика [1], С. Гончаренка [2], В. Загвязінського [3], Н. Кузьміної [4], П. Образцова [5], С. Сисоєвої [6] та інших науковців і проводилась упродовж 2011

дорожньому коледжі Національного університету “Львівська політехніка". Учасниками експерименту були об'єкти та суб'єкти дипломного проектування - викладачі професійно орієнтованих дисциплін, студенти коледжів автотранспортної галузі, випускники, керівники підприємств. В експериментальному дослідженні брало участь 437 студентів, що навчалися у коледжах автотранспортної галузі, 16 викладачів професійно орієнтованих дисциплін, 8 випускників коледжів, 10 керівників підприємств.

Для діагностики проектувальних умінь майбутніх техніків-механіків автотранспортної галузі було обгрунтовано та використано комплекс критеріїв: цільовий; мотиваційно-ціннісний; змістовий; операційний, творчий, результативний. Оцінюючи динаміку зростання проектувальних умінь ми використовували низький, достатній, середній і високий рівні їх сформованості. 3 огляду на номінальну факторну та результативну ознаки, для перевірки достовірності отриманих результатів у експериментальному дослідженні ми використовували критерій Пірсона $\left(\chi^{2}\right)$.

Проведення експериментального дослідження передбачало введення в навчальний процес активного педагогічного чинника. У його ролі було використано зміни у змісті дисципліни “Вступ до спеціальності”, у процесі вивчення котрої запроваджено практичні роботи зі створення ментальної карти для встановлення інтегративних зв’ язків між дисциплінами з виходом кінцевого результату на дипломний проект. У процесі

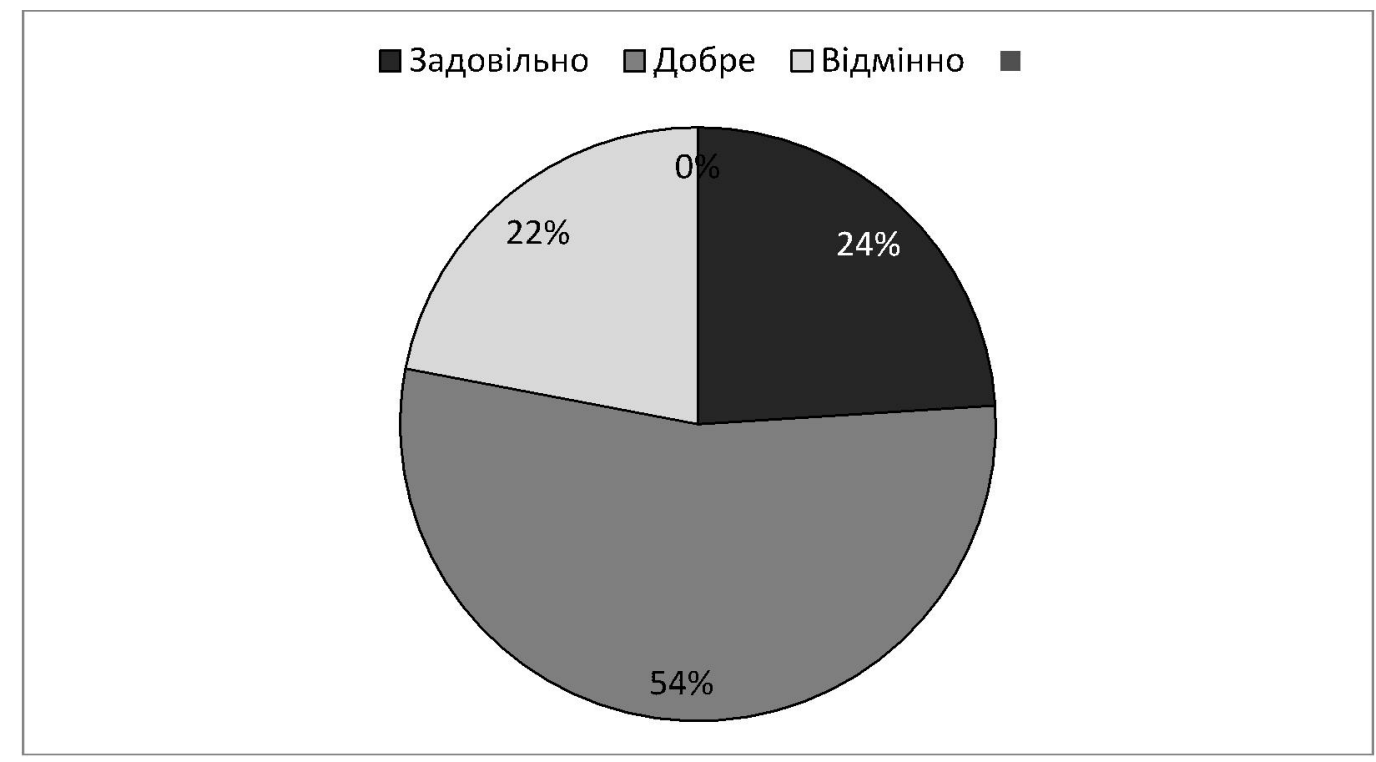

Рис. 1. Усереднені оцінки за дипломні проекти студентів коледжу 
ДОСЛДНО-ЕКСПЕРИМЕНТАЛЬНАПЕРЕВІРКАЕФЕКТИВНОСТІ

ФОРМУВАННЯПРОЕКТУВАЛЬНИХ УМІНЬ У МАЙБУТНІХ ТЕХНІКІВ-МЕХАНІКІВ АВТОТРАНСПОРТНОӤ ГАЛУЗІ В ПРОЦЕСІ ВИВЧЕННЯПРОФЕСІЙНО-ОРІСНТОВАНИХ ДИСЦИПЛІН

складання ментальної карти студент формує своє портфоліо з накопиченням інформації з кожної дисципліни починаючи з другого курсу. Зокрема, завдання на практичні роботи $з$ дисципліни “Нарисна геометрія" співпадають із тими, що виконуються під час дипломного проектування.

Перед навчальною та переддипломною практикою студент одержував конкретне завдання тобто тему дипломного проекту. Провідна ідея полягала в тому, що робота над дипломним проектом розпочинається з вивчення дисципліни “Вступ до спеціальності”, де опанувавши програму “MindManager” на кожній дисципліні студент складає окрему ментальну карту, бо одержані вміння та навички згідно освітньо-кваліфікаційної характеристики забезпечують оволодіння матеріалом кожної подальшої дисципліни, а також практичної роботи і курсових проектів. Так реалізується наступність професійної підготовки.

Дослідження стану формування проектувальних умінь студентів коледжів за результатами успішності захисту дипломного проекту здійснювалася шляхом експертного оцінювання та вивчення статистики оцінок безпосередньо за дипломні проекти студентів. Оцінки за виконання дипломних проектів дають можливість установити рівень сформованості проектувальних умінь у майбутніх техніків-механіків автотранспортної галузі, водночас оцінки експертів дозволяють виявити ключові вміння для підвищення ефективності формування проектувальних умінь.

На рис. 1. представлені усереднені оцінки за чотири навчальні роки за дипломні проекти студентів-випускників Львівського автомобільнодорожнього коледжу НУ “Львівська Політехніка".

Як бачимо 3 рис. 1, лише $22 \%$ випускників коледжу на “відмінно" захищають дипломні проекти і майже чверть, 24 \% - одержують оцінку “задовільно”. Це не може, на наш погляд, задовольнити сучасні вимоги до висококваліфікованих фахівців автотранспортної галузі - однієї з найбільш прогресивних і високотехнологічних, що динамічно розвивається. Отже, доцільним є новий підхід до дипломного проектування та формування проектувальних умінь студентів у цілому.

На констатувальному етапі дослідження було також досліджено експертну оцінку важливості та рівня сформованості проектувальних умінь. Відповідно до галузевого стандарту вищої освіти ми виділили 16 умінь і дисципліни, в процесі вивчення котрих ці вміння формуються (Табл. 1). Після цього за допомогою експертів здійснювалось їх оцінювання у студентів та розподіл на три групи за важливістю. Зокрема, до третьої групи відносимо найбільш вагомі: читання та виконання машинобудівних креслень; навички використання програмних засобів; уміння підбирати необхідне технологічне обладнання; володіння сучасними методами виготовлення та відновлення деталей; уміння організувати виробничий процес; уміння розробляти заходи 3 охорони праці. Сформованість цих умінь на констатувальному етапі дослідження відповідає переважно середньому рівню.

Експертне оцінювання сучасних тенденцій у підготовці майбутніх фахівців автотранспортної галузі (розроблення нових стандартів освіти, збільшення обсягу та підвищення ефективності навчальної практики, упровадження в навчання професійних IКТ, застосування інтегративного підходу, залучення студентів до професійної творчості) дало підстави стверджувати, що проектувальні вміння майбутніх техніків-механіків автотранспортної галузі мають значний потенціал для покращення.

Під час формувального етапу педагогічного експерименту були поставлені та виконані завдання, пов'язані з апробацією створеної моделі формування проектувальних умінь техніківмеханіків автотранспортної галузі під час вивчення професійно орієнтованих дисциплін, реалізацією й уточненням педагогічних умов, необхідних і достатніх для продуктивного їх формування. Успішному оволодінню студентами комплексом проектувальних умінь сприяло вдосконалення методичних підходів і конкретизація технологій, запропонованих із метою покращення професійної підготовки майбутніх техніків-механіків у коледжах автотранспортної галузі, а також упровадження авторської методики формування проектувальних умінь студентів під час вивчення ними професійно орієнтованих дисциплін.

Для цього було досліджено показники ефективності формування окремих компонентів визначених експертами найбільш вагомих професійних умінь третьої групи у студентів експериментальної та контрольної груп. Виявлені відмінності між ЕГ і КГ є систематичними, тобто викликані використанням нашої методики, а сформованість кожного вміння в експериментальній групі має вищий рівень.

Узагальнений показник визначався як загальна здатність випускників до дипломного проектування та подальшої професійної діяльності та розраховувався як усереднене значення шести показників (рис. 2.) 
ДОСЛДНО-ЕКСПЕРИМЕНТАЛЬНАПЕРЕВІРКАЕФЕКТИВНОСТІ

ФОРМУВАННЯПРОЕКТУВАЛЬНИХУМІНЬ У МАЙБУТНІХ ТЕХНІКІВ-МЕХАНІКІВ АВТОТРАНСПОРТНОӤ ГАЛУЗІ В ПРОЦЕСІ ВИВЧЕННЯПРОФЕСІЙНО-ОРІЕНТОВАНИХ ДИСЦИПЛІН

Таблиця 1.

Проектувальні вміння та дисципліни, що їх формують

\begin{tabular}{|c|c|c|}
\hline № & Дисципліна & Проектувальне уміння \\
\hline 1 & Українська мова & Письмова та усна комунікація рідною мовою \\
\hline 2 & Вища математика & Використання математичних методів \\
\hline 3 & Технічна механіка & $\begin{array}{l}\text { Виконання розрахунків елементів конструкцій на міцність, } \\
\text { визначення геометричних характеристик плоских перерізів }\end{array}$ \\
\hline 4 & Нарисна геометрія & Читання та виконання машинобудівних креслень \\
\hline 5 & $\begin{array}{l}\text { Інженерна та комп’ютерна } \\
\text { графіка }\end{array}$ & Використання програмних засобів \\
\hline 6 & Основи екології & Розроблення заходів з охорони навколишнього середовища \\
\hline 7 & Безпека життєдіяльності & $\begin{array}{l}\text { Розроблення заходів } 3 \text { промислової санітарії, техніки безпеки і } \\
\text { протипожежної безпеки }\end{array}$ \\
\hline 8 & Матеріалознавство & $\begin{array}{l}\text { Визначення на практиці фізико-механічних властивостей } \\
\text { матеріалів }\end{array}$ \\
\hline 9 & Деталі машин & $\begin{array}{l}\text { Володіння сучасними методами розрахунку та конструювання } \\
\text { деталей }\end{array}$ \\
\hline 10 & $\begin{array}{l}\text { Стандартизація та технічні } \\
\text { вимірювання }\end{array}$ & Володіння методами стандартизації \\
\hline 11 & Електротехніка & $\begin{array}{l}\text { Забезпечення надійної та ефективної експлуатації } \\
\text { електроприводів машин і обладнання }\end{array}$ \\
\hline 12 & ДВ3, автомобілі та трактори & $\begin{array}{l}\text { Організація безпечної та надійної експлуатації } \\
\text { автотранспортних засобів }\end{array}$ \\
\hline 13 & Експлуатація машин & Добір необхідного технологічного обладнання \\
\hline 14 & Ремонт машин & $\begin{array}{l}\text { Володіння сучасними методами виготовлення та відновлення } \\
\text { деталей }\end{array}$ \\
\hline 15 & Економіка підприємства & Організація виробничого процесу \\
\hline 16 & Охорона праці & Розроблення заходів з охорони праці \\
\hline
\end{tabular}

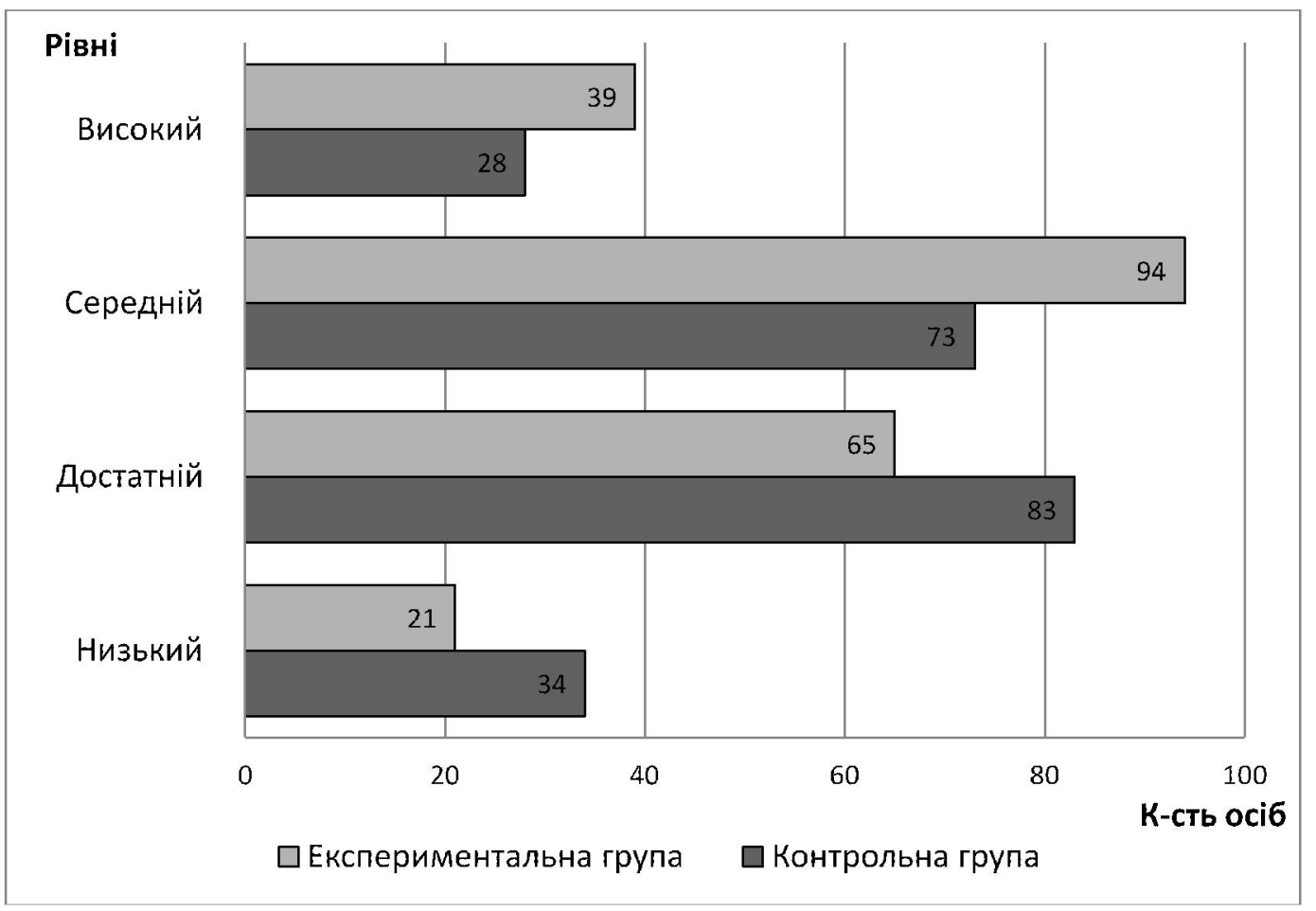

Рис. 2. Рівень сформованості узагальнених проектувальних умінь майбутніх техніківмеханіків у контрольній та експериментальній групах 


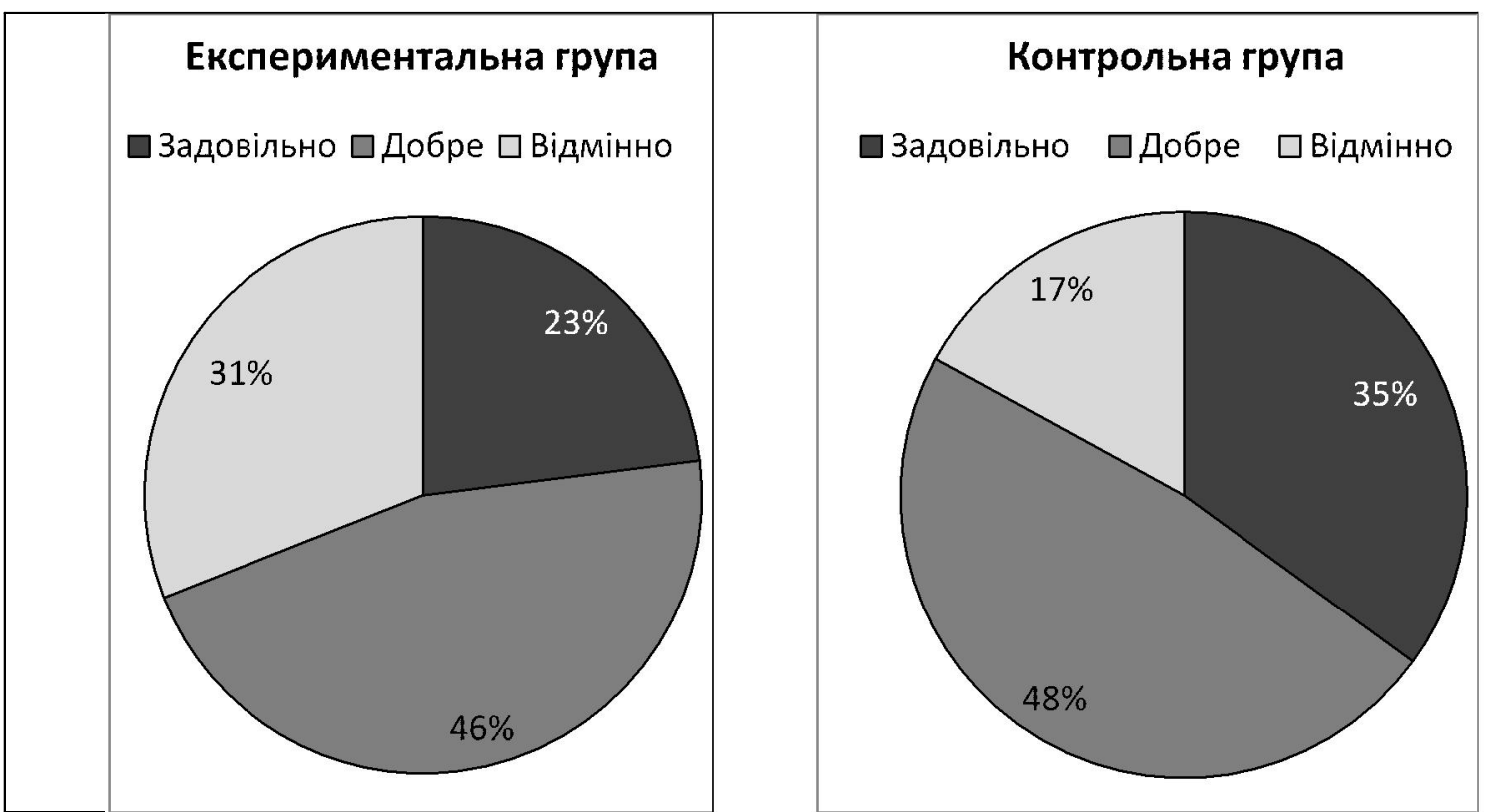

Рис. 3. Результати оцінювання дипломних проектів майбутніх техніків-механіків автотранспортної галузі в контрольній та експериментальній групах

Отримані результати студентів, які навчалися за нашою методикою, суттєво відрізняються, зокрема в експериментальній групі на низькому рівні менше на 13 осіб (6,0\%), на достатньому рівні менше на 18 осіб (8,4\%), на середньомурівні більше на 21 особу $(9,4 \%)$ і на високому рівні більше на 10 осіб (5\%). Тобто сформованість узагальнених проектувальних умінь в експериментальній групі значно вища. Такі показники свідчать про ефективність використання розроблених підходів, зокрема створення інтелектуальних карт, до формування проектувальних умінь майбутніх фахівців автотранспортної галузі.

3 метою додаткового підтвердження дієвості побудованої моделі. обгрунтованих педагогічних умов і розробленої методики проведено порівняння успішності виконання дипломного проектування в контрольній та експериментальній групах, результати яких подано на рис. 3 .

Як бачимо, усереднені оцінки за дипломні проекти майбутніх техніків-механіків автотранспортної галузі у контрольній та експериментальній групах значно відрізняються. В експериментальній групі в порівнянні 3 контрольною на 14 \% більше оцінок "відмінно" (17\% проти $31 \%$ ) і на $12 \%$ менше "задовільно" ( $23 \%$ проти $35 \%$ ), у той час як оцінок “добре” приблизно однаково (46 \% у ЕГ і 48 \% у КГ).

Висновки та перспективи подальших досліджень. Таким чином, результати формувального експерименту підтвердили гіпотезу нашого дослідження. Аналіз результатів дає підстави стверджувати, що в процесі експерименту підвищились рівень знань, умінь і навичок та професійна компетентність випускників коледжів. Формувальний етап педагогічного дослідження свідчить про суттєве покращення якості підготовки техніків-механіків автотранспортної галузі унаслідок впровадження запропонованих моделі, педагогічних умов і методики. Експериментальне дослідження підтвердило, що ефективна реалізація авторської теоретичної моделі та педагогічних умов формування проектувальних умінь техніківмеханіків автотранспортної галузі під час вивчення професійно орієнтованих дисциплін можлива лише в разі цілеспрямованого здійснення комплексу методичних заходів на основі співпраці викладачів різних дисциплін.

Пошук нових теоретичних і методичних рішень у професійній підготовці техніків-механіків автотранспортної галузі потребує подальших досліджень особливостей, тенденцій і принципів формування проектувальних умінь під час вивчення професійно орієнтованих дисциплін, теоретичного обгрунтування та розроблення дієвих механізмів формування комплексу проектувальних умінь майбутніх техніківмеханіків, розроблення інноваційних педагогічних технології професійної підготовки, які позитивно впливатимуть на ефективність формування професійної компетенції майбутніх техніківмеханіків автотранспортної галузі. 


\section{ЛІТЕРАТУРА}

1. Воловик П. М. Теорія імовірностей і математична статистика в педагогіці. Київ, 1969. 222 с

2. Гончаренко С. У. Педагогічні дослідження : Методологічні поради молодим науковцям. Київ; Вінниця, 2008. $278 \mathrm{c.}$

3. Загвязинский В., Атаханов Р. Методология и методы психолого-педагогического исследования : учеб. пособие для студ. высш. пед. учеб. заведений ; 4е изд. Москва, 2006. 208 с.

4. Методы системного педагогического исследования : учеб. пособие / под ред. Н. В. Кузьминой. Ленинград, 1980. $172 \mathrm{c}$

5. Образцов П. И. Методы и методология психологопедагогического исследования. Санкт-Петербург, 2004. $268 \mathrm{c}$

6. Сисоєва С. О., Кристопчук Т. Є. Педагогічний експеримент у наукових дослідженнях неперервної професійної освіти : навч.-метод. посіб. Луцьк, 2009. $460 \mathrm{c}$

\section{REFERENCES}

1. Volovyk, P. M. (1969). Teoriia imovirnostei $i$ matematychna statystyka $v$ pedahohitsi [Theory of probabilities and mathematical statistics in pedagogy]. Kyiv, 222 p. [in Ukrainian].
2. Honcharenko, S. U. (2008). Pedahohichni doslidzhennia : Metodolohichni porady molodym naukovtsiam [Pedagogical research: Methodological advice for young scientists]. Kyiv; Vinnytsia, 278 p. [in Ukrainian].

3. Zagvyazinskiy, V. \& Atahanov, R. (2006). Metodologiya i metodyi psihologo-pedagogicheskogo issledovaniya : ucheb. posobie dlya stud. vyissh. ped. ucheb. zavedeniy; 4-e izd [Methodology and methods of psychological and pedagogical research : Tutorial for higher school students]. Moscov, $208 \mathrm{p}$. [in Russian]

4. Kuzmina, N. V. (Ed.). (1980). Metodyi sistemnogo pedagogicheskogo issledovaniya : ucheb. posobie [Methods of systematic pedagogical research : Tutorial]. Leningrad, 172 p. [in Russian].

5. Obraztsov, P. I. (2004). Metodyi i metodologiya psihologo-pedagogicheskogo issledovaniya [Methods and methodology of psycho-pedagogical research]. SanktPeterburg, 268 p. [in Russian].

6. Sysoieva, S. O. \& Krystopchuk, T. Ye. (2009). Pedahohichnyi eksperyment $u$ naukovykh doslidzhenniakh neperervnoi profesiinoi osvity: navch.metod. posib. [Pedagogical experiment in scientific researches of continuous vocational education : Manual]. Lutsk, 460 p. [in Ukrainian].

Стаття надійшла до редакції 11.04.2019

УДК 37.013:001.89(045)

DOI:

Тетяна Гуркова, старший викладач кафедри початкової освіти Комунальний заклад "Запорізький обласний інститут післядипломної педагогічної освіти” Запорізької обласної ради

\section{ДЕФІНІЦІЇ ПОНЯТЬ “ОСВІТНІЙ ПРОСТІР”, “СЕРЕДОВИЩЕ”, “ОСВІТНС СЕРЕДОВИЩЕ”}

У статті представлено сутність понять “освітній простір”, “середовище”, “освітнє середовище”. Узагальнено результати аналізу різних наукових позицій щзоо трактування смислу досліджуваних феноменів. Окреслено основні смислові відмінності циих педагогічних конструктів. Наголошено на їх багатовимірності й різноплановості. 3'ясовно, що термін “освітнє середовище” є одним із ключових психолого-педагогічних понять. Простежено історичні зміни в змісті освітнього середовища, які були започатковані видатними педагогами.

Ключові слова: освітній простір; середовище; освітнє середовище.

Jim. 14.

Tetyana Hurkova, Senior Lecturer of the Primary Education Department Municipal Institution "Zaporizhzhya Regional Institute Postgraduate Pedagogical Education” Zaporizhzhya Regional Council

\section{DEFINITION OFTHE CONCEPTS “EDUCATIONAL SPACE”, "ENVIRONMENT", "EDUCATIONAL ENVIRONMENT"}

The article is devoted to research of different approaches to the interpretation of the concepts: "an educational space", "an environment", "and an educational environment". It has been found out that in the psychological and pedagogical theory and practice there is no single understanding concerning the interpretation of these terms, there is any established perception of them.

On the basis of the analysis, the essence of the concepts "an educational space", "an environment", "an 